\title{
İşitme Engelliler İçin Dil İçi Ayrıntıı Altyazı Uygulamaları
}

\author{
Practices of Intralingual Subtitling for the Deaf and Hard of Hearing
}

\author{
Araştırma/Research
}

\section{Şerife DALBUDAK}

Dr. Öğretim Üyesi, Çankaya Üniversitesi, Fen-Edebiyat Fakültesi, Mütercim-Tercümanlık Bölümü, sdalbudak@cankaya.edu.tr. ORCID: http//orcid.org/0000-0002-1223-4467

\begin{abstract}
ÖZET
Sağır ve işitme engelliler için ayrıntılı altyazı çevirisi gibi yeni çeviri türleri veya uygulamalarının çeviribilim sınıflarına taşınmasında çeşitli zorluklar ortaya çıkmaktadır. Bunlardan ilki, piyasadaki aktörlerin, çevirmenlerin ve kanalların tek tip bir uygulama benimsememeleridir. Her kanal, izleyicilerinden aldığı dönüt ışığında, kendi doğru bulduğu yöntemleri izleyerek belli uygulamaları benimsemektedir. Bu durum yalnızca Türkiye'de değil, tüm dünyada geçerlidir. Dolayısıyla, evrensel bir ayrıntılı altyazılama kılavuzu veya uygulanması gerekenlerin sıralandığı bir kitapçık yoktur. Bu koşullar altında, uygulayıcılar, en başarıı buldukları uygulamaları benimserler. Çalışmanın giriş bölümünde, öncelikle ayrıntılı altyazı uygulamalarının tarihçesi ve türün gelenekleri üzerinde durulmuştur. Girişin ardından, bu çalışma kapsamında, çeviribilim sınıflarında, ayrıntılı altyazı eğitiminde öğrencilere farklı uygulamaların örnek gösterilmesi yoluyla verilen eğitimin önemi, derste incelenen iki diziden (Engelsiz Kanal D'de yayınlanan Arka Sokaklar ve Netflix'te yayınlanan Elementary dizilerinden) alınan örnekler üzerinden gidilerek verilmiştir. Bu dizilerin ayrıntılı altyazı örneklerinin uygulamalarındaki mantık benzerlikleri ancak uygulama farklılıkları üç temel eksen (konuşmacının belirlenmesi, ses ve efektin belirlenmesi, nida, duygu ve vurgu aktarımı) esas alınarak incelenmiştir. Sonuç bölümünde ise, farklı uygulamaların örneklendirilmesi yoluyla verilen eğitimin amacının, çeviribilim öğrencilerinin, hem piyasada farklılaşan uygulamalara hakim olması, hem de işveren kılavuzlarının ve bunlara uyulmasının önemi vurgulanmıştır. Çalışma, çeviribilim sınıflarında, özellikle engelsiz erişim gibi, yaygınlaşan, ancak her ülkenin kendi gelenekleriyle beslenen çeviri türlerinde uygulamadan çıkarımla, örneklerden hareketle ilkeleri benimsetmenin doğru bir yaklaşım olabileceğinin altını çizmek için kaleme alınmıştır.
\end{abstract}

Anahtar Sözcükler: Engelsiz erişim, ayrıntılı altyazı çevirisi, altyazı çevirisi eğitimi.

\begin{abstract}
There are a range of different issues and challenges that need to be addressed for successful training in subtitling for the deaf and hard of hearing viewers (SDH) in the translation classroom. One of these challenges is due to the fact that actors in the field (translators and channels) do not work with standardized (SDH) guides. Different channels tailor different models and practices according to feedback they get from
\end{abstract}


end users. Thus, good practices are used as a basis for each channel to develop their own SDH guidelines. The initial part of the study deals with the history and conventions of SDH. This is followed by the introduction of a SDH training strategy in which students are trained through study of differing examples. In the analysis part, SDH of two series (Arka Sokaklar broadcast by engelsiz KanalD and Elementary broadcast by Netflix) are introduced and different strategies practiced in SDL are examined by addressing three variables; the designation of subtitles, voices and effects, and exclamations, emphasis and emotions. In conclusion, the study is an example of how translation students can be trained through concentrating on differing examples from various guidelines set by various actors. The study aims to underline that examples can be an ideal model in translation classes especially in a field that not only grows but constantly changes.

Key Words: Accessibility, subtitling for the deaf and hard of hearing (SDH), SDH training.

\section{Giriş}

Çeviribilim sınıflarında eğitimcinin karşılaştığı zorluklardan biri, teknolojinin getirdiği yenilikleri derslere taşıyarak çeviri piyasasında gerçekleşen değişiklikleri takip etmektir. Özellikle medya ve görsel-işitsel ürünler için yapılan çeviri türleri günden güne gelişmekte ve çeşitlenmektedir. Ülkelerin yeni politikaları, Sivil Toplum Kuruluşlarının (STK) girişimleri, sektör aktörlerinin yeni açılımlarıyla sürekli yenilikler yapılmakta ve farklı çeviri türleri ortaya çıkmaktadır (Okyayuz \& Kaya, 2017). Bu konu irdelenecek olursa, bundan birkaç yıl öncesine kadar Türkiye'de sesli betimleme, işaret diliyle görsel-işitsel çeviri veya bu çalışmanın kapsamını oluşturan Sağırlar ve işitme engelliler için altyazı çevirisi (ayrıntılı altyazı çevirisi) gibi uygulamaların olmadığı dikkati çekecektir. Oysa günümüzde bunlar, televizyonlarda reklamı yapılan, belli kanalların ve STK'ların girişimiyle yaygın olarak uygulanan ve çeviribilim öğrencilerinin haberdar olduğu çeviri türleri olarak karşımıza çıkar.

Dünyanın birçok ülkesinde sesli betimleme, işaret diliyle görsel-işitsel çeviri, ayrıntılı altyazı çevirisi gibi çeviri türlerine ilişkin araştırmalar oldukça yoğundur. Bunun önemli bir nedeni, ülkelerin televizyonlara ve kanallara erişimi sağlamak için bu çeviri türlerinin yapılmasına ilişkin zorunlu kotalar getirmeleridir. Devlet politikaları ile desteklenen bu uygulama yaygınlaştıkça, araştırma da gerekli hale gelmektedir. Türkiye'de ise erişim sağlamak amacıyla yapılan çeviri türlerine ilişkin zorunlu kotalar konmamıştır. Uygulamanın gün geçtikçe yaygınlaşması kanalların şahsi teşebbüsü ve maddi desteği sayesinde olmaktadır. Sonuç olarak da bu konuda yapılmış kayda değer Türk kaynaklı çalışmaya rastlamak pek de olası olmamaktadır. Öte yandan, çağın gereği yaşanan farklı gelişmelerden söz edilmesi yerinde olacaktır: Teknoloji, medyaya erişim olanaklarının gelişmesi, yeni erişim politikalarının şekillenmesi, azınlığa gönderimin önem kazanması gibi gelişmeler, uygulamada daha fazla çeviri türü ortaya çıkmasına neden olmaktadır (Okyayuz \& Kaya, 2016b).

Bütün bu gelişmelere bağlı olarak, Türkiye'de de farklı görsel-işitsel çeviri türleri yaygınlaşmaktadır. Her ne kadar istisnalar olsa da, farklı çeviri türlerini destekleyen yayın platformları ve çevirmenler, akademik çalışmalardan ve üniversitelerden kopuk bir şekilde işlerini yürütmektedirler. Ortaya çıkan yeni çeviri türleri farklı gerçekler ve 61 
ilkelerle şekillenmekte, değişik izleyici kitlelerine hitap etmektedir. Dolayısıyla, görselişitsel çeviri dersi almış bir çeviribilim mezununun bu çeviri türleri hakkında bilgisinin olması gerçeği doğmaktadır.

Bu düşünceden hareketle, bu çalışma kapsamında, çeviribilim sınıflarında, ayrıntılı altyazı eğitiminde öğrencilere farklı uygulamaların örnek gösterilmesi yoluyla verilen eğitimin önemi, derste incelenen iki diziden alınan örnekler üzerinden gidilerek verilmeye çalışılacaktır. Farklı uygulamaların örneklendirilmesi yoluyla verilen eğitimin amacı, çeviribilim öğrencilerinin hem piyasada farklılaşan uygulamalara hakim olmaları, hem de işveren kılavuzlarının ve bunlara uyulmasının önemini vurgulamaktır. Buna ilaveten, öğrenci, bir edimde ne kadar farklı uygulamalarla erişim sağlandığını görerek çevirmen seçimleri gibi konularda zengin bir birikim sahibi olabilir. Çeviribilim sınıflarında, özellikle engelsiz erişim gibi yaygınlaşan, ancak her ülkenin kendi gelenekleriyle beslenen çeviri türlerinde, uygulamadan çıkarımla, örneklerden hareketle ilkeleri benimsetmek doğru bir yaklaşım olarak benimsenebilir.

\section{Erişim ve çeviri:}

Başka bir dilde, kültürde oluşturulan bir bilgiyi, kurguyu, duyguyu ve benzerini, söz konusu dili veya kültürü bilmediğinden dolayı erişimi olmayan bir kitleye aktarmak için çeviri yapılır. Dolayısıyla, çeviri erişim sağlamak amacıyla yapılır. Günümüzde ise erişimden öte, engelsiz erişim kavramı ön plana çıkmaktadır. Engelsiz erişim, fiziksel bir engel yüzünden (örneğin, görme, işitme engeli) bir kaynak metne erişimi olmayan bireylere erişim sağlamak için yapılan çeviri türlerinin hepsini kapsar. Bu bağlamda, hem dil içi, hem de diller arası çeviri yapılmaktadır. Hatta aynı kaynak metin, birçok farklı şekilde çevrilmekte, böylece değişik kitlelere erişim olanağı sağlanmaktadır. Örneğin, bir yabancı dizinin işitme engelliler için Türkçe altyazı çevirisi (ayrıntılı altyazılama), işaret dili çevirisi ve dublaj çevirisinin üstüne sesli betimlemesi yapılabilmektedir.

Söz konusu çalışmada üzerinde durulan, Sağır ve işitme engelliler için yapılan ayrıntılı altyazı çevirisi türü, birçok örneğinde dil içi bir uygulama olarak icra edilir (örneğin, Türk dizilerine erişim için ayrıntılı altyazı yazılması yapılır). Dolayısıyla, bunun söylenenleri ekranın altına kısaltarak yazıp birkaç 'ses efektinin' de eklenmesiyle gerçekleşen bir uğraş olduğunu düşünenler bulunmaktadır. Oysa çok daha karmaşık olan ve çevirmenlik mesleğinin bir parçası olan bu edimin, özellikle eğitimli çevirmenler tarafından bilinmesi ve kavranması hak ettiği özenin gösterilmesi açısından oldukça önemlidir.

2000'li yıllarda, toplumsal düzeyde bilinçlenme, teknolojik olanakların yaygınlaşması ve gelişimi, Birleşmiş Milletler Engelli Hakları Sözleşmesi gibi uluslararası girişimler, sivil toplum kuruluşlarının ve derneklerin yaygınlaşması ve etkili hâle gelmesi ile azınlığa gönderim ve engelli kişiler için erişim konuları önem kazanmıştır (Okyayuz 
ve Kaya, 2016). Bu nedenle, farklı çeviri ortamlarının ve erişim türlerinin belli bir yetkinlik, belli bir bilgi ve beceri seti gerektirdiği gerçeği göz önünde bulundurulmalıdır.

$\mathrm{Bu}$ alanda önde gelen araştırmacılardan biri olan L. Bogucki (2015, s. 10), günümüzde yapılan görsel-işitsel çeviri araştırmalarında değişik çeviri türlerini, değişik gönderim kanallarını, çeviri yapma biçimlerini erek izleyiciler açısından incelemenin önemini vurgular. Erişimin altında birçok etkinlik betimlenebilir. Örneğin, J. Diaz Cintas (2005, s. 4), erişimi geniş bir kapsamda tanımlayarak, belli bir kitle için anlaşılması güç olan bilgi ve eğlence kaynaklarının ediniminin kolaylaştırılması olarak betimler. Erişimi kolaylaştıran çeviri türlerinden bir kaçı, işitme engelliler için altyazı tekniklerinin geliştirilmesi, işitme engelliler için işaret dili çevirmenliğinin görsele eklenmesi, işitme engelliler için canlı altyazı çevirisi, tiyatroda sesli betimleme ve görme engelliler için sesli betimleme olarak sıralanabilir (Okyayuz, 2016, s. 37-40).

Çeviribilim mezunu bir öğrencinin belli alanlarda uzmanlık bilgisi edinmesi, farklı uygulamalara hakim olması ve öğrendiği uygulamaların kendi içinde de farklılık gösterebileceğini özellikle bilmesi önemli bir konudur. Diğer bir konu ise, çeviribilim mezunu olmanın ya da çeviride deneyim sahibi olmanın hiçbir ek çaba veya gelişme göstermeden, engelsiz erişim için kullanılan çeviri türlerini uygulayabilmek anlamına gelmediğidir. Çevirmenin, çeviri türü ne olursa olsun başarıyla yapılabilmesi için öncelikle alıcı kitlenin kültürüne çok yakın olması, ihtiyaçlarını ve sınırlarını çok iyi bilmesi gerekir. Halbuki, Türkiye'de günümüzde ayrıntılı altyazı gibi dil içi çeviriyi gerektiren engelsiz erişim türlerinde üniversite düzeyinde bir eğitim verilmediğinden, özellikle bu türlerin kimler tarafından uygulanacağı tartışma konusudur, hatta çevirmenin faaliyetleri arasına girmesine gerek olmadığını düşünenler bile vardır. 0 yüzden, altı çizilmesi gereken konu, engelsiz erişim çeviri türlerinin çevirmenin ek bir eğitim almadan yapabileceği çeviri türleri olmadığı gerçeğidir. Engelsiz erişim için çeviri türleri kendi içlerinde farklılaştığı gibi (örneğin, ayrıntılı altyazı ile işaret dili çevirisi), alıcı kitleleri açısından (örneğin, Sağırlara ve görme engellilere yönelik türler) ve yine kendi içinde uzmanlık alanı açısından da farklılaşmaktadır (örneğin, görsel-işitsel ürünlere erişim için yapılan çeviri ile kamu hizmetlerine erişim için yapılan çeviri). Engelsiz erişim için yapılan çeviri türlerini, hem türler üzerinde durarak (örneğin, sesli betimleme, ayrıntılı altyazı, işaret dili çevirisi) hem de farklı uzmanlıkları ayrı ayrı irdeleyerek incelemek mümkündür (örneğin, görsel-işitsel metinlere erişim için kullanılan çeviri türleri).

Yukarıda sözü edilen konuların ışığı altında, bu çalışmada, engelsiz erişimi kolaylaştırmak için yapılan çeviri türlerinden biri olan Sağır ve işitme engelliler için ayrıntılı altyazı uygulaması üzerinde durulacaktır. Bu türün dil içi uygulamasında Türkiye'de yaygın bir şekilde takip edilen bir Türk kanalı olan Kanal D'de (engelsiz Kanal D uygulamaları) sunulan Türkçe ve yabancı menşeli Netflix kanalında sunulan İngilizce ayrıntılı altyazı örneklerinin uygulamalarında ortaya çıkan farklılıklar incelenmiştir. Belli bir görsel-işitsel türü ile konuyu kısıtlı tutmak amacıyla polisiye diziler seçilmiş ve bu 
yolla örneklerin bütünlüğü sağlanmaya çalışılmışıı. Bu türün seçilme nedenlerinden birinin sınıf içi uygulamalarda tüm öğrencilere hitap etmesi olduğunu da vurgulamak gerekir.

\section{3. İşitme Engelliler için Altyazı - Ayrıntılı Altyazı}

İsitme engelliler için altyazı 1970-80'li yıllarda uygulanmaya başlanmışır ve eşzamanlı altyazı çevirisi ilk olarak Amerika Birleşik Devletleri ve İngiltere'de yapılmaya başlanmıştır (Neves, 2005, s. 107). Her ne kadar Avrupa'da, bazı ülkelerde sıkça yapılan bir çeviri türü olsa da Amerika Birleşik Devletleri ve İngiltere'de olduğu kadar yaygınlık göstermemektedir. Günümüzde Türkiye'de Digitürk ve Netflix gibi platformlarda ve diğer bazı kanallarda gün geçtikçe daha fazla yaygınlaştığı gözlemlenmektedir. Ayrıntılı altyazı çevirisinin bir ülkede benimsenmesi ve yaygınlaşması için bir takım önkoşulların sağlanması oldukça önemlidir. Bu önkoşullara örnek olarak okuma yazma oranının yüksek olması gerektiği verilebilir. Buna ek olarak, görsel-işitsel çeviri kavramı ve şemsiyesi altında toplanabilecek değişik çeviri alt türlerinin uygulanması, uygulanış biçimi, yoğunluğu her ülkenin kendi tarihi, gerçekleri ve gelenekleri çerçevesinde şekillenecektir (Okyayuz ve Kaya 2017, s. 43-45).

Wurm (2007, s. 115), işitme engelliler için ayrıntılı altyazı çevirisi yapılırken, ister dil içi ister diller arası olsun, konuşulan diyalogları yazıya dökme aşamasında, çevirmenin bir takım bilgiler ışı̆̆ında seçimlerini ve çevirisini yönlendirmesi gerektiği üzerinde durur. Bu konuda yoğun çalışmalar yürüten Neves (2009, s. 167), işitme engelliler için diller arası altyazı çevirisini geliştirmek amacıyla, işitme engelli gruplarla çalışılması ve işitme engelli bireylerin gereksinimlerinin araştırılması gerektiğini vurgular. Szarkowska (2013, s. 68), işitme engelliler için yapılan diller arası altyazı çevirisinin, dil içi altyazı çevirisinden ve de işitme engeli bulunmayan diğer izleyiciler için yapılan diller arası altyazı çevirisinden bazı açılardan farklılaştığııı altını çizer. Neves $(2008$, s. 128) ise işitme engelliler için yapılan altyazı çevirisi konusunda, hem toplumda hem de çeviribilimciler arasında bir takım yanlış anlaşılmalar olduğunu vurgular. Dil içi altyazı çevirisi ve işitme engelliler için altyazı çevirisi her zaman aynı uygulama değildir. İşitme engelliler homojen bir grup değildir ve farklı ihtiyaçları olan alt gruplara ayrılabilir. Her grubun gereksinimleri, okuma hızları ve kaynak görselişitselle etkileşim şekilleri birbirinden farklılık gösterecektir (Neves 2008, s. 128).

Her ne kadar işitme engelliler için altyazı normlarını ortaya koyan bir takım kılavuzların oluşturulması gerekse de, bu kılavuzların değişik ülkelerdeki izleyicilerin intiyaçları doğrultusunda şekillenmesi ve değişiklik göstermesi doğru olacaktır. İşitme engelliler için, dil içi altyazı çevirisi uygulamasında bir eğitime gerek olmadığını düşünenler ve dil içi altyazı çevirisinin, duyduğunu yazmaktan ibaret olduğunu farz edenler, yapılması gereken kısaltmalar, teknik kısıtlar, zaman ve uzam kısıtlamaları nedeniyle bu türün altyazılarının belli intiyaçları olan bir gruba yönelik olarak tasarlanacağından, belirli düşünceler ışı̆̆ında şekillenmesi gereğinin farkında 
değillerdir. Örnek vermek gerekirse, sözlü iletişim yazıya döküldüğünde akıl karıştırıp anlaşılmaz hale gelebileceği için bu türün çevirisinde diyalogların aynen aktarılması doğru değildir (Neves 2008, s. 128-139).

Öte yandan, genel bir ayrıntılı altyazı ilkeleri bütününden söz etmek yanlış olacaktır. Her görsel-işitsel çeviri türünde, uygulandıkları yere bağlı olarak genel geçer kabul görmüş bazı ilkeler olabileceği gibi, çeviri ediminin ve şeklinin ülkeden ülkeye değişebileceğinin de üzerinde durulması önemlidir. Örneğin, altyazı çevirisinin, diyalogların ekranın alt tarafında verildiği bir çeviri türü olduğu genel bir ilke olarak kabul edilse de, kullanılacak satır ve karakter sayısı, bunun rengi, zamanlaması ve ekranda konumlandırılması ülkeden ülkeye, hatta aynı ülke içinde farklı kanallara göre değişiklik göstermektedir. Bu bağlamda, her ne kadar tektipleştirilmiş bir ilkeler bütünlüğüne varmak mümkün olmasa da Delabastita $(1989$, s. 199) tarafından da vurgulandığı üzere çevirmenin irdelemesi ve üzerinde durması gereken göstergeler mevcuttur: İlk olarak görsel olarak sunulan dilsel göstergeden bahsedilebilir: Ekranda yer alan tüm yazılı metinler bu başlık altında ifade edilebilir. Sokak levhalarından mektuplara, gazetelerin gösterilmesinden ekranda tarih veya yer ile ilgili açıklayıcı bilgi verilmesine kadar, görsel olarak sunulan birçok dilsel gösterge örneği verilebilir. İkincisi, görsel olarak sunulan dilsel olmayan gösterge: Filmin yukarıda sözü edilenler dışında kalan tüm görseli. Üçüncü gösterge, işitsel olarak sunulan dilsel gösterge: Film boyunca duyulan tüm diyaloglara ek olarak, şarkı sözleri ve karakterlerin ağzından çıkan bütün sesler ve nidalar bu başlık altında derlenebilir. Son gösterge ise, işitsel olarak sunulan dilsel olmayan gösterge: Enstrümantal müzik ve arka fondan gelen bütün ses efektleri (kapının çalınması, arabaların fren sesi vb.) bu başlık altında örneklenebilir.

Dolayısıyla, görsel-işitsel çeviriye başlamadan önce çevrilecek ürünün dikkatlice incelenmesi ve irdelenmesi gerekli ve önemlidir. O yüzden, bir görsel-işitsel çeviri türü olan ayrıntılı altyazı çevirisi yapan çevirmenin işinin işitsel düzgüdeki çoğu ve/ya tüm bilgiyi başka bir dile ve kültüre aktardığı düşüncesi, ayrıntılı altyazı çevirisine kısıtı bir bakış açısıdır. Ayrıntılı altyazı çevirisi bu kadar basit veya tek boyutlu bir uğraş değildir. Her şeyden önce, altyazı çevirmeninin çeviri yaparken görsel-işitsel ürünün çok düzgülülüğünden kaynaklanan anlamsal tabakaları olduğunu unutmaması gerekir. Tüm bu düşüncelerden yola çıkarak, aşağıda örneklenen, çeviribilim sınıflarında yapılan çalışma tasarlanmıştır.

\section{4. Çeviribilim Sınıflarında Yapılan Çalışma}

İşitme engelliler için ayrıntılı altyazı çevirisi gibi yeni çeviri türleri veya uygulamalarının çeviribilim sınıflarına taşınmasında çeşitli zorluklar ortaya çıkmaktadır. Bunlardan ilki, piyasadaki aktörlerin, çevirmenlerin ve kanalların tek tip bir uygulama benimsememeleridir. Her bir kanal, izleyicisinden aldığı dönüt ışığında, kendi doğru bulduğu yöntemleri izleyerek belli uygulamaları benimsemektedir. Bu aslında yalnızca 
Türkiye'de değil, dünyanın her yerinde böyledir. İşitme engelliler için ayrıntılı altyazı uygulamasında iyi uygulama örnekleri bulunmaktadır. Bu konuda araştırmacıların kullanıcılarla yaptığı çalışmalar da vardır. Ancak, ülkeden ülkeye, izleyici kitlesinden bir diğerine değişen uygulamalar benimsenmiştir. Evrensel bir ayrıntılı altyazılama kılavuzu veya mutlaka uygulanması gerekenlerin sıralandığı bir kitapçık yoktur. Bu koşullar altında da uygulayıcıların, iyi uygulama örneklerinden yola çıkarak en iyi olduğunu düşündükleri uygulamaları benimsemeleri gerekir. Örnekleri incelerler, kendi izleyicilerinden gelen dönütleri dikkate alırlar, uygulayıcılarıyla konuşurlar ve sonuç olarak bir kılavuz ortaya koyarlar ve bazı gelenekleri benimserler.

Bu çalışma kapsamında, çeviribilim sınıflarında, ayrıntılı altyazı eğitiminde öğrencilere farklı uygulamaların örnek gösterilmesi yoluyla verilen eğitimin önemi, derste incelenen iki diziden alınan örnekler üzerinden gidilerek verilmeye çalışılacaktır. Farklı uygulamaların örneklendirilmesi yoluyla verilen eğitimin amacı, çeviribilim öğrencilerinin, hem piyasada farklılaşan uygulamalara hakim olmasını sağlamak, hem de işveren kılavuzlarının ve bunlara uyulmasının önemini vurgulamaktır. Ayrıca, bu yolla öğrenci, bir edimde ne kadar farklı uygulamalara erişim sağlandığını görerek çevirmen seçimleri gibi konularda zengin bir birikim sahibi olacaktır.

Bu nedenle, çeviribilim sınıflarında özellikle engelsiz erişim gibi yaygınlaşan ancak her ülkenin kendi gelenekleriyle beslenen çeviri türlerinde uygulamadan çıkarımla, örneklerden hareketle ilkeleri benimsetmek doğru bir yaklaşım olarak benimsenebilir. Ayrıntılı altyazı derslerinde benzer bir yaklaşım benimsenmiş ve örneklemeli derslerde, öğrencilere piyasadan alınan çağdaş ve yaygın örnekler incelettirilmiş, bundan çıkarımla ayrıntıı altyazının gerçekleri ortaya konmuştur.

Derslerde izlenen yaklaşım aşağıdaki şekilde şematize edilebilir: 


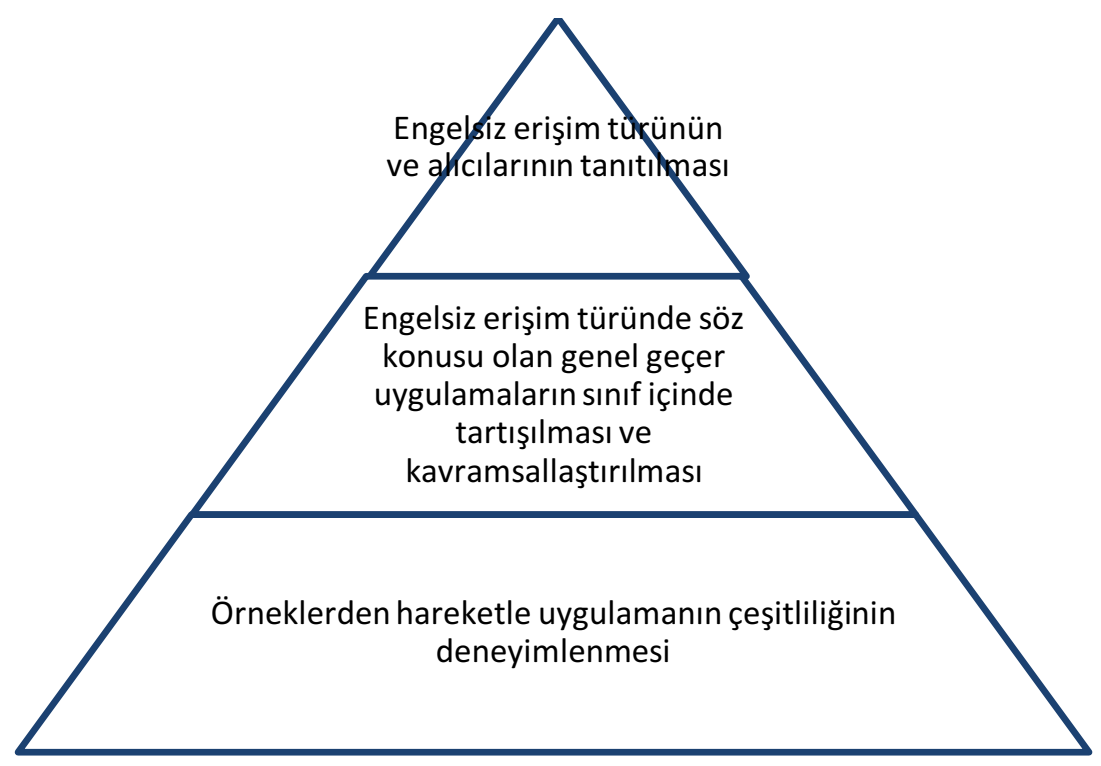

Bu yaklaşımla, öğrencinin hem piyasadaki ana oyuncuların uygulamaları ile aşina olması, hem de farklı uygulamaların ilkelerini ve artı ve eksilerini görmesi sağlanabilmektedir. Verilen eğitim ise şu şekilde ifade edilebilir:

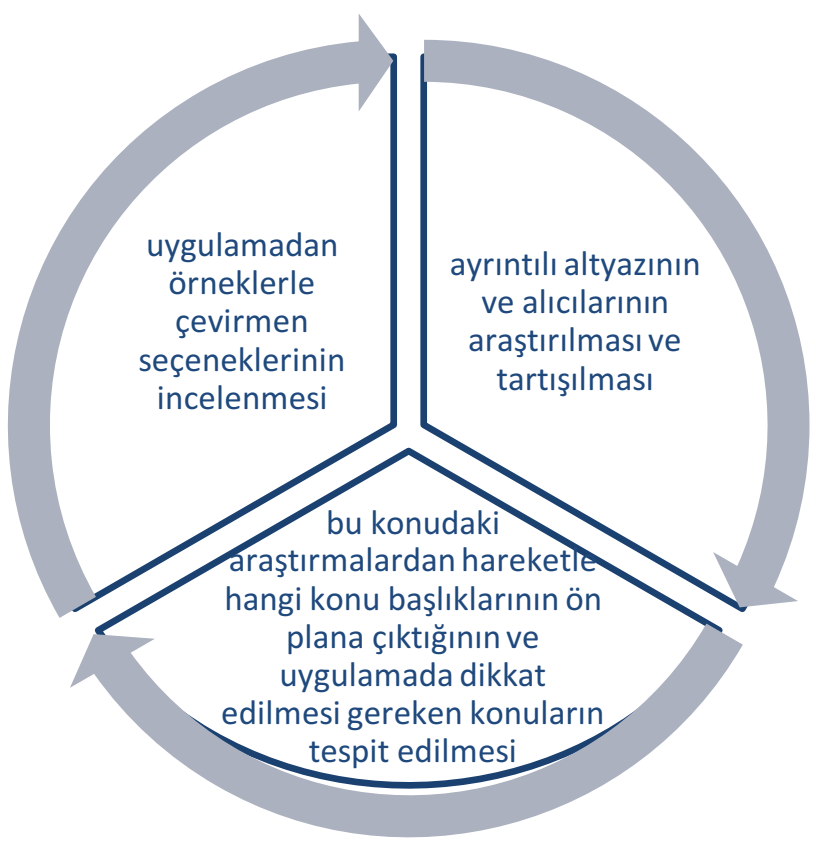


Aşağıda bu eğitim sırasında ve sürecinde izlenen yoldan örnekler verilecektir:

\section{1. Çalışmanın Örnekleme Ekseni}

Yukarıda belirtilen konulardan hareketle, bu çalışma bağlamında Sağır ve işitme engelliler için ayrıntılı altyazı uygulaması üzerinde durulmuştur. Bunun dil içi uygulamasında Türkiye'de yaygın bir şekilde takip edilen bir Türk kanalı olan Kanal D'de (engelsiz Kanal D uygulamaları) sunulan Türkçe ve yabancı menşeli Netflix kanalında sunulan İngilizce ayrıntılı altyazı örneklerinin uygulamalarındaki mantık farklılıkları üç temel esas ele alınarak incelenmiştir. Belli bir görsel-işitsel türü ile konuyu kısıtlı tutmak amacıyla polisiye diziler seçilmiş ve böylece örneklerin bütünlüğü sağlanmaya çalışılmıştır. Ayrıca, polisiye dizilerin sınıf içi uygulamalarda tüm öğrencilere hitap eden bir tür olduğu için seçildiğinin de altını çizmek gerekir.

Uygulamalardaki farklılıkları incelemek için Kanal D'de yayınlanan Arka Sokaklar adlı dizinin 486.Bölümü ve Netflix kanalında yayınlanan Elementary adlı dizinin While You're Sleeping (Sen Uyurken) adlı 2. Öyküsü (Episode 2) aşağıdaki eksenler çerçevesinde incelenmiştir:

a. Konuşmacının belirlenmesi (konuşan kişilerin adlarının nasıl verildiği)

b. Ses ve efektin belirlenmesi

c. Nida, duygu ve vurgu aktarımı

\subsubsection{Konuşmacının Belirlenmesi}

\subsubsection{Arka Sokaklar Dizisi- Bölüm 486 (Kanal D)}

İnceleme için Kanal D’de yayınlanan Arka Sokaklar dizisinin 486. Bölümü seçilmiştir. Öğrencilere öncelikle 2006 yılından bu yana izlenme rekorları kıran dizi ile ilgili bilgi verilir. Sonrasında belirlenen kesit öğrencilerle birlikte izlenir. Ayrıntılı altyazı uygulamasında ilke olarak, konuşan karakterlerin adlarının replikleriyle birlikte verilmesinin önemi vurgulanır. Öğrencilerden konuşmacının nasıl belirlendiğine yani adların nasıl verildiğine odaklanmaları istenir.

Tablo 1.

Konuşmacının Belirlenmesi

\begin{tabular}{|c|c|}
\hline Konuşma & Süre \\
\hline $\begin{array}{c}\text { (Rıza dış ses)insanın } \\
\text { Olduğu her yerde suç vardır. }\end{array}$ & 00.30 \\
\hline (Rıza dış ses) Suçun & 00.32 \\
\hline
\end{tabular}




\begin{tabular}{|c|c|}
\hline Olduğu her yerde de biz & \\
\hline (Rıza dış ses) Bazen geç bazen erken. & 00.34 \\
\hline $\begin{array}{c}\text { (Rıza dış ses) Ama mutlaka bir şekilde } \\
\text { orada oluruz. }\end{array}$ & 00.36 \\
\hline $\begin{array}{l}\text {...kanun ne diyorsa onu yapmak } \\
\text { için. }\end{array}$ & 00.39 \\
\hline $\begin{array}{c}\text { (Rıza dış ses) İnsanların yarası neredeyse } \\
\text { oraya merhem olmak için. }\end{array}$ & 00.41 \\
\hline Ama bu son meselede... & 00.47 \\
\hline $\begin{array}{l}\text {...çocukların birer birer ortadan } \\
\text { kaybolduğu günlerde... }\end{array}$ & 00.51 \\
\hline $\begin{array}{l}\text {...ister istemez soruyorum } \\
\text { kendi kendime }\end{array}$ & 00.54 \\
\hline Bu insanlar aynı insanlar mı? & 00.57 \\
\hline (Rıza) Bu sokaklar ne zaman değişti? & 01.00 \\
\hline Biz nasıl kendi çocuklarını... & 01.02 \\
\hline $\begin{array}{l}\text {...kendilerinden koruyamayan } \\
\text { bir toplum olduk? }\end{array}$ & 01.04 \\
\hline $\begin{array}{c}\text { Bu yara nerededir, } \\
\text { merhem nereye sürülecek? }\end{array}$ & 01.06 \\
\hline (Rıza) Önce bu çocukları bulmalıyız. & 01.10 \\
\hline $\begin{array}{l}\text { Sonra şapkayı önümüze koyup hep } \\
\text { beraber düşünmeliyiz. }\end{array}$ & 01.12 \\
\hline Haklısınız Rıza Müdür'üm. & 01.15 \\
\hline $\begin{array}{c}\text { Gerekli önlemleri hep } \\
\text { birlikte düşünüp almamı... }\end{array}$ & 01.18 \\
\hline ...üstümüze ne düşüyorsa yapmamız lazım. & 01.20 \\
\hline $\begin{array}{c}\text { Ama önceliğimiz kayıplarımız, } \\
\text { bu dört evladımız. }\end{array}$ & 01.22 \\
\hline Ekiplerimiz soluksuz çalışıyor. & 01.27 \\
\hline $\begin{array}{l}\text { Bir dahaki toplantımızda umarım iyi } \\
\text { haberlerle karşınızda olacağız. }\end{array}$ & 01.30 \\
\hline
\end{tabular}

Belirlenen kesit, öğrencilerle birlikte izlendikten sonra uygulamanın özellikleri birlikte tartışılır. Öncelikle dizinin Türkçe sürümünde ilk olarak konuşanın kim olduğu konuşmacının kadraja girmediği noktada (Rıza dış ses şeklinde) verilmiştir. Sahne değiştiği sürece konuşmacı belirlenmiş ama sahnenin aynı kalması durumunda (bakınız 00.39 saniye) konuşmacı kadraj dışında bile olsa konuşma sadece üç nokta (...) ile 
verilmiştir. Dış ses olarak belirlenen konuşmacı, (00.47) saniyede kadraja girmiş ama konuşmacının kadraja girmesiyle engelsiz izleyici ve engelli izleyicinin durumu eşitlendiği düşüncesiyle konuşmacının adı verilmemiştir. Bu saniyeden itibaren birden fazla konuşmacının bir masa etrafında yaptıkları konuşmada engelli izleyicinin olayı takip etmesi en az engelsiz izleyici kadar kolaylaştığı için oldukça akılcı bir uygulama takip edilmiş ve kameranın odaklandığı kişi Rıza komiser değilse, izleyici Rıza komiseri tanıyor düşüncesiyle konuşmacı belirlenmemiştir. Masa etrafında süregelen konuşmada diğer kişilerin adı, konuşurlarken kamera yüzlerine odaklandığı ve konuşmalarında Rıza komisere referans gösterdiklerinden nasılsa Rıza komiserin konuşmasıyla karışmaz düşüncesiyle verilmemiştir.

Sınıf içinde yapılan çalışmalarda üzerinde durulan bir diğer örnekte ise:

Tablo 2.

Konuşmacının Belirlenmesi

\begin{tabular}{|c|c|}
\hline Konuşma & Süre \\
\hline $\begin{array}{c}\text { (Rıza) Herkesin önceliği } \\
\text { bu çocuklar Arif. }\end{array}$ & 01.38 \\
\hline $\begin{array}{c}\text { İstediğin zaman bizim ekipten de } \\
\text { görevlendirme yapabilirsin. }\end{array}$ & 01.43 \\
\hline Söylememe gerek yok, değil mi? & 01.45 \\
\hline Biliyorum Rıza sağ ol. & 01.48 \\
\hline Işim düşerse anında kapındayım. & 01.50 \\
\hline Ekip nasıl her şey yolunda mı? & 01.54 \\
\hline Yolunda, yolunda. & 01.57 \\
\hline Yolunda olsun diye uğraşıyoruz. & 01.59 \\
\hline
\end{tabular}

Konuşarak binadan çıkan Rıza komiser ve arkadaşı birlikte kadrajda oldukları için yine sadece Rıza adı belirlenmiş diğer konuşmacının adı izleyici Rıza komiseri tanıdığı ve aynı zamanda diğer konuşmacı Rıza komisere adıyla hitap ettiğinden dolayı verilmemiştir.

\subsubsection{Elementary Dizisi - While You're Sleeping (Sen Uyurken) Episode 2 (2.Öykü)} (Netflix):

Yapılan incelemede uygulama farklılıkları bağlamında örneklemeler yapmak için ikinci dizi olarak yine bir polisiye dizi olan Elementary seçilmiştir. Aynen Arka Sokaklar dizisinde olduğu gibi öğrencilere Elementary dizisiyle ilgili kısa bir bilgi verildikten sonra belirlenen kesit öğrencilerle birlikte izlenir. Aşağıdaki örnekte de verileceği üzere, İngilizce ayrıntılı altyazı sürümüyle yayınlanan bu dizinin uygulamasında Türkçe ayrıntıı 
altyazı sürümüyle yayınlanan Arka Sokaklar dizisindeki uygulamadan farklılıklar gözlemlenmiştir:

\section{Tablo 3.}

Konuşmacının Belirlenmesi

\begin{tabular}{|c|}
\hline $\begin{array}{l}\text { MAN: } \\
\text { I have been sober for two years, } \\
\text { Seven months, and } 13 \text { days now. }\end{array}$ \\
\hline $\begin{array}{l}\text { I could...give you } \\
\text { how many hours in seconds, }\end{array}$ \\
\hline $\begin{array}{l}\text { But then you might think } \\
\text { I'm obsessive. (chuckles) }\end{array}$ \\
\hline I guess I just want to say... \\
\hline thank you. \\
\hline Uh, without these meetings, \\
\hline $\begin{array}{l}\text { Without the support } \\
\text { of people like you, }\end{array}$ \\
\hline I just don't know where I'd be. \\
\hline (people clapping) \\
\hline $\begin{array}{l}\text { MODERATOR: } \\
\text { Thanks, Eric. }\end{array}$ \\
\hline
\end{tabular}

Arka Sokaklar dizisinde verilen ayrıntılı altyazı uygulamasından farklı olarak ayrıntılı altyazı sürümü İngilizce olan bu dizide öncelikle biçem farklılıkları göze çarpmaktadır. Tablo 3'e bakıldığında, konuşmacının MAN (Adam) ya da MODERATOR (Moderatör) yazılarak belirlendiğinin ve bu kelimelerin büyük harflerle yazıldığının altı çizilebilir. Türkçe sürümde ise konuşmacının kim olduğu, konuşmanın başında parantez içinde verilmiştir. Ayrıca, MAN kelimesinin ayrı satırda verilmesi ile ayrıntılı altyazı uygulamasında üç satır kullanıldığı gözden kaçmayacaktır. Oysa, ayrıntılı altyazı uygulamalarının ilkelerinin üzerinde durulduğu derslerde öğrencilere ideal olanın iki satır olduğu öğretilmektedir. Kadrajın sürekli değişmesine rağmen MAN kelimesinin tekrarlanmaması da altı çizilebilecek diğer bir farktır. Değişen sahnede hala aynı kişinin konuştuğunu vurgulamak için ise üç nokta (...) kullanılmaktadır. Öte yandan, belki de Türkçe sürümle İngilizce sürüm arasındaki en temel fark, İngilizce sürümde konuşma metninin kısa olması yani yer olması koşuluyla konuşmaların tam karakterlerin altına gelecek şekilde verilmesidir. Türkçe sürümde tire işareti (-) ile alt alta yazılan konuşma metinler, İngilizce sürümde kısa olması koşuluyla yan yana karakterlerin altına yazılmaktadır. Böylece karakterlerin adının belirlenmesine gerek kalmamaktadır. 
Öte yandan, uygulamalardaki farklılıkları irdeleyen bu çalışmanın karşılaştırma ekseni olarak ele almadığı başka bir takım biçem farklılıkları da göze çarpmaktadır. Örneğin, İngilizce sürümde, yazı tipi (font) ve yazı büyüklüğü (size) Türkçe sürümden farklıdır. Daha büyük ve alışılagelmemiş bir yazı tipi benimsenmiş ve yazılarda koyu renk (bold) seçilmiştir.

\subsubsection{Ses ve Efektin Belirlenmesi}

\subsubsection{Arka Sokaklar Dizisi Bölüm 486 (Kanal D):}

Ayrıntılı altyazı uygulamalarında ortaya çıkan farklılıkların incelendiği bu çalışmanın ikinci eksenini ses ve efektin nasıl belirlendiği oluşturmaktadır. Türkçe sürümü üzerinde durulan Arka Sokaklar adlı dizide, ses ve efektler aşağıdaki tabloda verildiği üzere parantez içinde yazılarak belirlenmiştir:

\section{Tablo 4.}

Ses ve Efektin Belirlenmesi

\begin{tabular}{|l|}
\hline (Müzik/Jenerik) \\
\hline (Rıza dış ses) \\
\hline (telsiz erkek ses) \\
\hline (öksürme sesi) \\
\hline (ayak sesleri) \\
\hline (silah sesi) \\
\hline (vurma sesi) \\
\hline (kapı kapanma sesi) \\
\hline
\end{tabular}

4.1.2.2.Elementary Dizisi - While You're Sleeping (Sen Uyurken) Episode 2 (2.Öykü) (Netflix):

Aşağıdaki örnekler incelendiğinde görüleceği üzere Türkçe ve İngilizce sürümler karşılaştırıldığında geleneklerde kayda değer farklılıklar olduğu göze çarpmaktadır. Öğrencilerin bu farklılıkları yakalayıp hem Türkçe hem de İngilizce sürümlerde dil içi gelenekleri iyi öğrenmelerini ve ayrıntılı altyazı uygulamasında belirtilmesi gerekenlere hakim olmalarını sağlamak en büyük amaçtır.

Tablo 5.

Ses ve Efektin Belirlenmesi

\begin{tabular}{|l|}
\hline (chuckles) \\
\hline (people clapping) \\
\hline (clears throat) \\
\hline
\end{tabular}




\begin{tabular}{|l|}
\hline (smacks lips) \\
\hline (phone rings) \\
\hline (sniffing)/ (sniffs) \\
\hline (door shuts) \\
\hline (sighs) \\
\hline
\end{tabular}

İngilizce sürümde gelenek, fiile odaklanıp fiilin geniş zamanda verilmesiykenboğazını temizler, güler, ellerini çırparlar şeklinde- ayrıntılı altyazısı Türkçe olan dizide kahkaha ses, fotoğraf çekme sesi, gülme sesi yapısında isim cümlecikleri tercih edilmektedir. Ayrıca, biçemsel bir fark olduğunun da altını çizmek gerekir. Türkçe'de parantez içindeki ilk kelimenin ilk harfi büyük yazılırken İngilizce'de parantez içindeki kelimeler küçük harfler kullanılarak yazılmaktadır.

\subsubsection{Nida, Duygu ve Vurgu Aktarımı}

\subsubsection{Arka Sokaklar Dizisi Bölüm 486 (Kanal D):}

Çalışmanın son ekseni olarak nida, duygu ve vurgu aktarımı irdelenecektir. Sürümü Türkçe olan Arka Sokaklar adlı dizinin ayrıntılı altyazı uygulamalarında göze çarpan ilk unsur uygulamadaki ayrıntıdır. Burada konuşmanın en ince detayına kadar bütün duyguları verecek şekilde aktarımından bahsedilmektedir. Oysa, derslerde öğrencilere konuşmacının her söylediğinin altyazı da verilmesinin gerekli olmadığı, altyazının konuşmanın tümünü içeren bir döküm olmadığı vurgulanırken Türkçe dizinin ayrıntılı altyazı uygulaması ayrıntısıyla öne çıkmaktadır:

\section{Tablo 6.}

Nida, Duygu ve Vurgu Aktarımı

\begin{tabular}{|c|c|}
\hline Nida, Duygu, Vurgu & Süre \\
\hline Aa! Ben hiç gidemedim ya. & 03.06 \\
\hline Al bak renge bak renge, al bak. & 03.08 \\
\hline $\begin{array}{c}\text { E Mesut abi de yardımcı oluyordur tabii } \\
\text { çocukla falan. }\end{array}$ & 03.10 \\
\hline Tabii, tabii, tabii, ne demezsin. & 03.12 \\
\hline $\begin{array}{c}\text { Gel lan buraya } \\
\text { ah }\end{array}$ & 06.12 \\
\hline - Öldürdün lan çocuğu! \\
-Ah! ah!
\end{tabular}


Görüldüğü üzere ayrıntılı altyazısı Türkçe olan dizide, duyguların ve vurguların net olarak aktarılması adına konuşmacının ağzından çıkan her cümle kelimesi kelimesine verilmeye çalışılmıştır.

4.1.3.2. Elementary Dizisi - While You're Sleeping (Sen Uyurken) Episode 2 (2.Öykü) (Netflix):

Tablo 7.

Nida, Duygu ve Vurgu Aktarımı

\begin{tabular}{|c|}
\hline WOMAN: \\
Hey, what are you doing? \\
He's nuts. \\
\hline Your brain, hm? \\
\hline Useful facts. \\
\hline Useful, viscous, golden. \\
\hline Natterings. \\
\hline That's the stupidest thing \\
I've ever heard. \\
\hline It's how my brain works. \\
\hline
\end{tabular}

Yukarıdaki örnek incelediğinde, en göze çarpan unsurun vurgunun aktarımı adına " $m y$ " kelimesinin eğik yazı ile (yana yatmış şekilde) verilmesi olacaktır. Türkçe altyazı da vurgu tekrarlayan kelimelerle yapılırken İngilizce'de bu kelimenin eğik yazı kullanılarak yazılması ile yakalanmaya çalışılmıştır. Türkçe'dekinin aksine İngilizce'de ağızdan çıkan her kelime, her nida verilmemiş ama yine de “Hey, hm" gibi nidalar altyazıya aktarılmıştır.

Sınıfta yapılan bu alıştırmanın ardından öğrencilerin üzerinde düşünmeleri ve geliştirmeleri gereken konulara odaklanılır. Bunu bir örnekle ayrıntılandırmak yerinde olacaktır:

- Ayrıntılı altyazı geleneğinde alıcı kitlenin profili gereği konuşmacının yaptığı konuşma ile eşlenmesi gerekir. Bu eşleme konuşmacı adlarının (örn: Riza) veya konuşmacıyı tarif eden sıfatların (örn: Moderatör) diyalogun başına eklenmesiyle gerçekleşir. Bu ekleme yapılırken en basit kıstas, karakterin adının bilinip bilinmediğidir. Örneğin, ana karakterler tanınırken o bölümdeki konuk oyuncunun adının hemen bilinmesi beklenemez. Dolayısıyla ilk ilke, karakter ile repliğin eşlemesinin yapılmasının gerekliliğidir.

- Adlar repliklerle eşlenirken bunun sunumu kanaldan kanala değiş̧ebilir. illk olarak karakter adı ile diyalog ayrıştırılır. Ancak kimi durumda, bu büyük harf küçük harf farklılaştırılması ile, kimi durumda ayraçla, kimi durumda 
parantezle vb birçok farklı uygulama ile yapılabilir. Ayrıca, diyalogların ekran altına yerleştirilip yerleştirilmeyeceği, görüntüde yerinin oynayıp oynamayacağı da karakter adının yazılıp yazılmaması açısından önemlidir. Diyalog, konuşan kişinin altında yer alabiliyorsa o zaman adını yazmak gereksiz olabilmektedir. Böylece, ikinci ilke, karakter ile diyalog eşlenmesinde, altyazıların yazım gelenekleri ve uzamsal yerleşimleri dahil olmak üzere birçok unsurun sunumu etkilemesi olacaktır.

- Adların repliklerle eşlenmesinde görsel düzgüden bilgi ve destek alınır. Örneğin, karakterin yakın çekimde karede olduğu durumlarda adının yazııması gereksizken, dışarıdan sesinin duyulduğu durumlarda sesin nereden geldiğinin eklenmesi önemlidir. Bu durumda, üçüncü ilke, görselden karakter ve diyalog eşlemesinin yapılabileceği veya yapılamayacağı durumların saptanması ve ancak yapılamayacağı durumlarda ad girilerek eşleme yapılmasıdır.

Burada örneklenen şekilde bir yapılandırmayla yukarıda sözü edilen üç olgu hakkında öğrencileri düşündürmek ve bunu sınıf ortamında tartışmak oldukça önemlidir. Öğrenci bu şekilde uygulamayı tek tip bir kurallar silsilesi olarak değil, değişik durumlarda değişik kararlar verilmesi gereken bir bütünce olarak görebilecektir. Böylece, çevirmen olarak kararlarını ve seçimlerini eğitimli ve akılcı bir şekilde oluşturabilecektir. İşveren tarafından kendisine bir kılavuz sunulduğunda, bu kılavuzdaki uygulamaları değerlendirebilecek ve buna bağı olarak çevirisindeki bazı eksiklikleri bile giderebilecektir.

\section{Sonuç}

Üç eksen baz alınarak yapılan inceleme sonucunda, altyazı kısıtlarına ve son kullanıcıların profiline bağlı olarak ortaya çıkan ilkelerin, çeviribilim sınıflarında ayrıntılı altyazı uygulamalarında öğrenciye öğretilmesi gerektiği ve bu ilkelerin içselleştirilmesinin öneminin vurgulanmasının gerekliliği ortaya çıkmıştır. Gerek Engelsiz Kanal D gerekse Netflix gibi kanallarda sunulan sürümlerde yapılan uygulama farklılıklarının ayırdına varmak ve yine aynı kanallarda uygulamalar yapabilmek için belli başlı ilkelerin benimsenmesi, edinilmesi, uygulama mantığının çözülmesi ve sonuç olarak mantıklı ve akılcı bir uygulama ortaya konabilmesi bu eğitimin amacıdır. Hedeflenen eğitim, öğrencinin kaynak metni iyi çözümleyip akılcı bir erek metin oluşturabilmesidir.

Sürekli gelişen ve değişen görsel-işitsel çeviri piyasasına öğrenciler yetiştirilirken bu öğrencileri her an piyasadaki uygulamaları takip edecek şekilde yetiştirmek önemlidir. Sınıf içinde yapılacak uygulamalar öğrenci mezun olana kadar değişebilmekte, hatta öğretilenden farklı çeviri türleri bile ortaya çıkabilmektedir. Ancak, yukarıda örneklenen türden bir eğitimle kuramsal temelin üzerine oturtulmuş uygulama kaynaklı araştırmayla öğrenciye öğrenmeyi öğretmek, kendini geliştirmeyi öğretmek belki de gelişen ve değişen çeviri piyasasını çeviribilim sınıflarına taşımanın en akılcı yollarından biridir. 


\section{Kaynakça}

Bogucki, L., Deckert, M. (2015). Introduction: Accessing Audiovisual Translation, L. Bogucki, M. Deckert (ed.). Lodz Studies in Language Vol 35, Frankfurt Am Mein: Peter Lang Edition, 9-10.

Delabastita D. (1989). Translation and Mass-Communication: Film and TV Translation as Evidence of Cultural Dynamics. Babel 35(4), 193-218.

Diaz Cintas, J. (2005). Audiovisual Translation Today. A Question of Accessi-bility for All, Translating Today 4, 3-5.

Neves, J. (2005). Audiovisual Translation: Subtitling for the Deaf and Hard-of-Hearing, School of Arts, Roehampton-University of Surrey, Yayımlanmamış Tez. Roehampton.openrepository.com/roehampton/handle/10142/12580

C:/users/user/downloads/neves\%20audiovisual.pdf.

Neves, J. (2008). 10 fallacies about Subtitling for the d/Deaf and the hard of hearing, JoSTrans. The Journal of Specialised Translation, Issue 10. 128-143. http://www.jostrans.org/issue10/art neves.pdf.

Neves, J. (2009). Interlingual Subtitling for the Deaf and Hard of Hearing, Audiovisual Translation: Language Transfer on Screen, (Ed.) J. Diaz Cintas \& G. Anderman, Basingstoke: Palgrave Macmillan. 151-169.

Okyayuz, A.Ş. (2016). Altyazı Çevirisi. Ankara: Siyasal Kitabevi.

Okyayuz, A. Ş. \& Kaya, M. (2016). Erişim Çağında Azınlığa Gönderim ve bir Çeviri Türü olarak Sesli Betimleme. The Journal of Academic Social Science. Number 51. Autumn III.2016.

Okyayuz, A. Ş. \& Kaya, M. (2016b). Altyazı Çevirisi için bir Model Önerisi. International Journal of Languages Education and Teaching (IJLET). Year 4, volume 4, Issue 2, August 2016, 276-275.

Okyayuz, A. Ş. \& Kaya, M. (2017). Görsel-İşitsel Çeviri Eğitimi. Ankara: Siyasal Kitabevi.

Szarkowska, A. (2013). Towards interlingual subtitling for the deaf and hard of hearing. Perspectives: Studies in Translatology, 21(1). 68-81. DOI: 10.1080/0907676X.2012.722650.

Wurm, S. (2007). Intralingual and Interlingual Subtitling: A Discussion of the Mode and Medium in Film Translation. The Sign Language Translator and Interpreter (SLTI) Volume 1, Number 1. 115-141.

\section{Görsel-Iş̧itsel Kaynakça}

$\begin{array}{lllllll}\text { Arka Sokaklar. (2006-...). Yönetmen: Orhan } & \text { Oğuz. Yapım Şirketi:Erler Film A.Ş. } \\ & \text { engelsiz.kanald.com.tr/Video/Detail/30053/1 }\end{array}$

Elementary. (2012). Yönetmen: John Polson,John David Coles, Peter Berner. Yapım Şirketi:CBS

http://www.netflix.com/watch/80001171?tracked=13752289\&tctx 